\title{
Survival rate of immediate loaded one-piece zirconia dental implants - one year follow-up
}

\author{
Pinto AC*, Henriques I*, Chen A**, Canta JP,** Francisco H***, Caramês J**** \\ *Resident at Postgraduation Course in Oral Surgery, University of Lisbon Faculty of Dental Medicine \\ ** Assistant Lecturer at the Oral Surgery and Implant Dentistry Department at University of Lisbon Faculty of Dental Medicine \\ *** Assistant Professor at the Oral Surgery and Implant Dentistry Department at University of Lisbon Faculty of Dental Medicine \\ **** Full Professor at the Oral Surgery and Implant Dentistry Department at University of Lisbon Faculty of Dental Medicine
}

\section{INTRODUCTION}

Zirconia dental implants (ZDI) have been introduced as a valuable alternative to titanium implants as they present favorable characteristics. Biological aspects (good biocompatibility, low affinity to bacterial plaque, small amount of inflammatory infiltrate, good soft-tissue integration) $)^{1-3}$, physical and mechanical properties (low thermal conductivity, high flexural strength, fracture and corrosion resistance) $)^{1,3}$ and aesthetical behavior (white opaque color) $)^{1,3}$ have been reported as some advantages of ZDI. The purpose of this study was to evaluate the survival rate of single unit one-piece ZDI with immediate loading and to assess marginal bone loss (MBL).

\section{MATERIAL AND METHODS}

This retrospective case series study evaluated 7 patients treated with 10 single unit one-piece ZDI (Straumann ${ }^{\circledR}$ PURE Ceramic), with at least $10 \mathrm{~mm}$ long and $3.3 \mathrm{~mm}$ wide, inserted with a torque of at least $35 \mathrm{Ncm}$ and placed at healed sites ( $\geq 3$ months). 8 implants were placed in the upper jaw and 2 in mandibles. All patients received immediate non-occlusal loading with provisional acrylic crowns. Provisional crowns were replaced after 3 months by definitive full ceramic crowns. Outcome measures were implant survival rate and peri-implant $\mathrm{MBL}$ assessed using standardized radiographs at implant insertion and I year after placement (Kodak Carestream Dental).
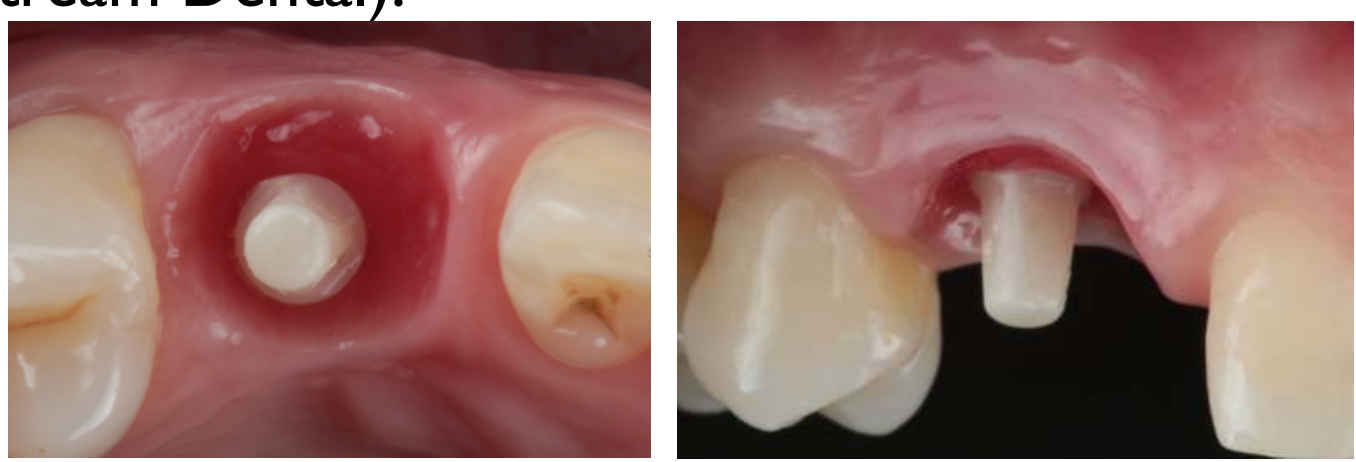

Figure I: Clinical photographs of one-piece ZDI I year after placement, in a frontal and in a occlusal view.; Radiograph at baseline.

\section{RESULTS}

One year after loading, no patients had dropped out and no implant was lost resulting in a survival rate of $100 \%$. No decementation of crowns occurred. The estimated MBL between baseline and I year of loading ranged between 0 and $1.98 \mathrm{~mm}$ with an average of $1.08 \mathrm{~mm}( \pm 0.5 \mathrm{~mm})$. In $40 \%$ of the implants a loss of less than $1 \mathrm{~mm}$ were observed.

\begin{tabular}{|c|c|c|c|c|c|c|}
\hline 74Di & Position & Length & Diameter & MBi & MBL & MBI \\
\hline 1 & 14 & 12 & 3,3 & 1.01 & 1.2 & 1.11 \\
\hline 2 & 16 & 12 & 3,3 & 0.89 & 0.98 & 0.94 \\
\hline 3 & 36 & 10 & 4.1 & 1.8 & 1.8 & 1.80 \\
\hline 4 & 11 & 12 & 4.1 & 1.34 & 1.56 & 1.45 \\
\hline 5 & 24 & 10 & 4.1 & 1.87 & 0.9 & 1.39 \\
\hline 6 & 26 & 10 & 3.3 & 0.6 & 0 & 0.30 \\
\hline 7 & 13 & 12 & 3.3 & 0.2 & 0.4 & 0.30 \\
\hline 8 & 15 & 12 & 4.1 & 0.8 & 0.6 & 0.70 \\
\hline 9 & 11 & 12 & 4.1 & 1.07 & 1 & 1.04 \\
\hline 10 & 43 & 10 & 4.1 & 1.98 & 1.5 & 1.74 \\
\hline
\end{tabular}

Table I: Implant details (position, length, diameter); MBL in mesial and distal sites and MBL mean $(\mathrm{mm})$.

\section{DISCUSSION}

The survival rate of ZDI in our study is $100 \%$. Recent studies reported survival rates that range between $77-100 \%{ }^{4-7}$. However, it must be considered that the studies examined different implant systems with diversity in implant design, surface modification, surgical and loading protocols, follow-up period, and type of prosthetic reconstruction.

The mean MBL in this study was $1.08 \mathrm{~mm}$. According to Albrektsson et al. (1986) ${ }^{8}, 1.5 \mathrm{~mm}$ of marginal bone loss during the first year followed by an annual bone loss not exceeding $0.2 \mathrm{~mm}$ is considered acceptable.

\begin{tabular}{|c|c|c|c|c|c|c|c|}
\hline Kohal R-J, et al. $(20 \mid 2)^{6}$ & $\begin{array}{l}\text { Prospective case } \\
\text { series study }\end{array}$ & $\begin{array}{l}66 \text { (I8 maxilla; } \\
48 \text { mandible) }\end{array}$ & $\begin{array}{l}\text { Either immediate or late } \\
\text { placement in healed sites }\end{array}$ & Single unit & 12 months & $95.4 \%$ & $1.31 \mathrm{~mm}$ \\
\hline Payer M, et al. (20 I 2)9 & $\begin{array}{l}\text { Prospective case } \\
\text { series study }\end{array}$ & $\begin{array}{l}20 \text { (I I maxilla; } \\
9 \text { mandible) }\end{array}$ & Healed sites & Single units & 24 months & $95 \%$ & $1.29 \mathrm{~mm}$ \\
\hline orgonovo A, et al. $(20 \mid 3)^{7}$ & Clinical study & $\begin{array}{l}28 \text { (20 maxilla; } \\
8 \text { mandible) }\end{array}$ & Healed sites & $\begin{array}{l}\text { Single or multiple } \\
\text { units }\end{array}$ & 48 months & $100 \%$ & $1.63 \mathrm{~mm}$ \\
\hline Roheling S, et al. $(2016)^{4}$ & $\begin{array}{l}\text { Retrospective } \\
\text { study }\end{array}$ & $\begin{array}{l}\text { I6I (84maxilla; } \\
77 \text { mandible) }\end{array}$ & $\begin{array}{l}\text { Healed sites ( } \geq 6 \\
\text { months) }\end{array}$ & $\begin{array}{l}\text { Single or multiple } \\
\text { units }\end{array}$ & 84 months & $77.3 \%$ & $\begin{array}{l}0.97 \mathrm{~mm} \\
( \pm 0.07)\end{array}$ \\
\hline
\end{tabular}

Table 2: Comparison of our results with published international data.

\section{Conclusion and Clinical Implications}

Despite the limitations of this study, ZDI seem to have similar results to titanium implants regarding osseointegration and MBL. Even so, further investigations are needed regarding the survival rates and clinical outcomes of ZDI. al. A retrospective clinical study with regard to survival and success rates of zirconia implants up to and after 7 years of loading. Clin Implant Dent Relat Res 2016 18: 545-558; 5.Spies BC, et al. Alumina reinforced zirconia implants: I-year results from a prospective cohort investigation. Clin Oral Implants Res 20I5: 27: 48I490;6. Kohal RJ, et al. One-piece zirconia oral implants: one-year results from a prospective cohort study. I. Single tooth replacement. J Clin Periodon- tol 20 I2: 39 590-597;7.Borgonovo AE, et al. Evaluation of the success criteria for zirconia dental implants: a four- year clinical and radiological study. Int Dent J 20I3: 20I3 463073;8.Albrektsson T, et al. The long-term efficacy of currently used dental implants: a review and proposed criteria of success. Int J Oral Maxillo- fac Implants 1986: I: II-25; 9.Payer M, et al. Immediate provisional restoration of single-piece zirconia implants: a prospective case series - results after 24 months of clinical function. Clin. Oral. Impl. Res. 00, 20 I2, I-7. 